\title{
Chapter 3 \\ Composting: A Sustainable Route for Processing of Biodegradable Waste in India
}

\author{
Ashootosh Mandpe, Sweta Kumari, and Sunil Kumar
}

\begin{abstract}
Surging populations, coupled with the ever-increasing demand for sustenance, have led to the generation of behemoth proportions of wastes throughout the globe. The processing of such a considerable amount of waste has raised concerns for environmental planners, policymakers, and researchers in regard to maintaining sustainability. Biodegradable waste is a part of the total waste stream. Consideration should be given to the importance of making better use of biodegradable waste. The technology that is adopted for the management of biodegradable waste should be ecologically sustainable and cost-effective, as well as beneficial to social wellbeing. The most efficient way of managing biodegradable waste must include different methods for the optimal utilisation of such waste, ranging from the small scale (single household) to the very large scale (entire city). Amid all the other waste processing technologies, composting stands out as a most potent option because of its ability to maintain and restore soil fertility, along with the transformation of waste into a resource. Composting is one of the few technologies which has a benefit-cost ratio higher than 1 at all scales of operation. This chapter analyses the most significant aspects of the composting process, including the recent developments and dynamics involved in it. The chapter discusses various aspects of composting via analysis of the integrated waste management system and composting-related projects implemented at the community level in the Indian context. Finally, the chapter presents policies and the efforts put in place by the Government of India with the aim of encouraging composting practice and related activities.
\end{abstract}

Keywords Biodegradable waste $\cdot$ Biological decomposition $\cdot$ Community-based implementation $\cdot$ Composting $\cdot$ Composting techniques $\cdot$ India $\cdot$ Municipal solid waste (MSW) management $\cdot$ Sustainable utilisation

\footnotetext{
A. Mandpe $\cdot$ S. Kumari $\cdot$ S. Kumar $(\bowtie)$

Council of Scientific \& Industrial Research (CSIR)-National Environmental Engineering and

Research Institute (CSIR-NEERI), Nagpur, India
} 


\section{Introduction}

The swelling population, along with ever-increasing demands, has led to the generation of behemoth volumes of waste. The waste generation rate is proportional to the human population throughout the globe. Management of these enormous volumes of generated waste tends to put pressure on urban local bodies governing the cities or the urban parts of the Indian country. In the twenty-first century, solid waste management has gained significant consideration from various environmental planners, policymakers, non-governmental organisations and waste managers because of the negative environmental impacts resulting from unscientific management and adoption of unsafe disposal practices in respect of waste. The situation is particularly distressing in developing countries: municipal solid waste (MSW) can be spotted almost ubiquitously in the urban as well as semi-urban parts of most developing countries. Eco-friendly MSW management has become a challenging task in India due to the increasing population, unparalleled and unalterable urbanisation, as well as industrial development (Ramachandra et al. 2018). To give an idea of the size of the problem, Table 3.1 presents today's MSW generated per capita in India and other developing countries, as well as the forecast figures (Hoornweg and BhadaTata 2012).

MSW poses a considerable risk to the surrounding environment, including water, soil, and human health. According to the Central Pollution Control Board (CPCB) report, the MSW in India has significantly higher fraction of organics (CPCB 2013a). Enormous volumes of biodegradable solids get generated as earthly and aquatic weeds, leaf litter, and agricultural waste. The weeds, if left untreated, may infest the land and water resources and may lead to their depletion. In developing nations, the practice of burning agricultural waste and leaf litter in the open air is still prevalent, which not only abolishes the significant deal regarding carbon and other nutrients but also causes air pollution, resulting in global warming.

According to Tomić and Schneider (2017), different approaches have been adopted as alternatives to traditional methods of solid waste management. These include the reuse of MSW and biodegradables waste, which is done via thermal processing and bioprocessing techniques. Thermal processing techniques comprise incineration, pyrolysis, and gasification; however, these do not seem feasible due to the low calorific values (800-1000 kcal/kg for Indian MSW) of MSW generated in developing countries, high energy intensiveness, as well as the fact that they result in other environmental hazards. Bioprocessing techniques comprise anaerobic digestion and composting. Among all other waste processing technologies, composting seems to be a powerful option because of its ability to maintain and restore soil fertility, along with the transformation of waste into a resource. Composting is among the best known processes for the biological stabilisation of biodegradable waste and is one of the few technologies which has a benefit-cost ratio greater than 1 for all scales of operation.

Composting can be explained as the process of transforming the organic substrate into nutrient-rich manure through the medium of microbial communities. The 


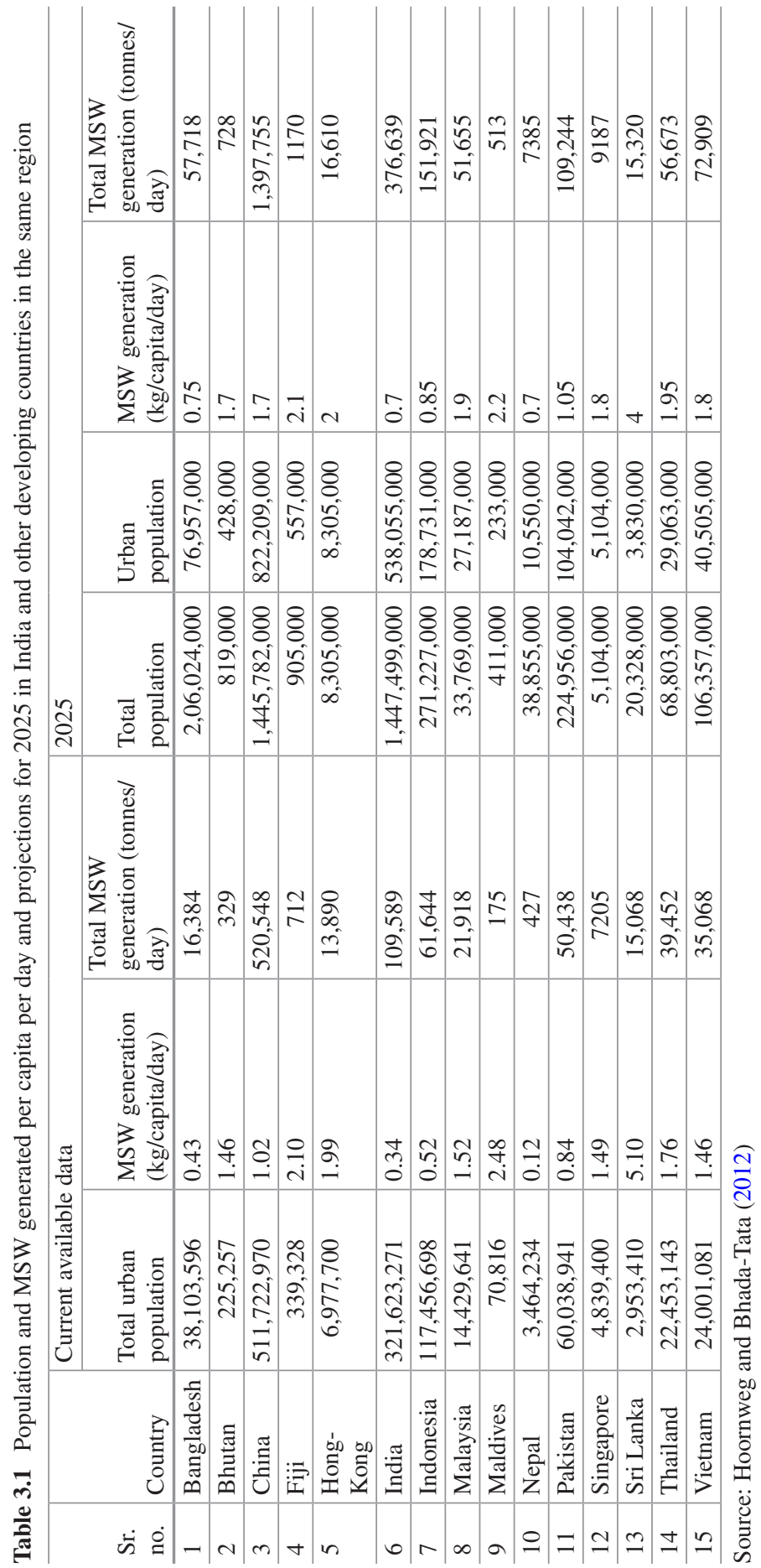


prerequisite of the composting process is the availability of substrate in an organic origin (Gajalakshmi and Abbasi 2008a). More precisely, composting signifies the process of the biodegradation of the mixture of organic substrate conducted by the populations of various microbial species in aerobic environments in the solid state.

The process of composting generally takes place in four phases, and they may occur concomitantly, rather than sequentially (Belyaeva and Haynes 2009). These four phases include:

(i) The mesophilic phase

(ii) The thermophilic phase

(iii) The cooling phase

(iv) The curing phase

During the initial phase (the mesophilic phase), which is also termed the decomposition phase, the bacterial community present in the mixture of organic substrate combines oxygen with carbon to produce energy and carbon dioxide. A portion of the energy is utilised by the microorganisms for growth and reproduction processes, and the rest is released as heat. In this stage, the oxidation of easily degradable organic matter takes place, along with the proliferation of mesophilic bacteria, resulting in a rise in temperature of the substrate to be composted. These mesophilic bacteria may include E. coli and other bacterial strains which are inhibited by the temperature as the process is taken over by the thermophilic bacteria in the transition range.

The next phase, i.e. the thermophilic phase, which is also termed the stabilisation phase, involves the mineralisation of slowly degradable molecules, along with complex process like humification of lignocellulosic compounds. In this stage, a rise in temperature can be observed, which lasts only for a few days. After the completion of a thermophilic phase, the available manure seems to be digested, but the bristlier materials will remain intact. This phase is the cooling phase, in which the mesophilic microbes, which were hurtled away during the thermophilic phase, take over the system and start digesting the more resilient organic constituents of the substrate. Fungi and other macroorganisms like earthworms also enter back into the system.

A long curing time acts as a safety net for the destruction of remaining pathogens. The immature compost can be detrimental to plants and may even result in the production of phytotoxins. These phytotoxins may deprive the soil of nitrogen and oxygen and can contain higher levels of organic acids (Vandergheynst 2009).

\section{Composting of Different Wastes}

Composting is a cost-effective and clean option for waste disposal. It also offers extra benefits such as reduction of greenhouse gas (GHG) emissions, space taken by the landfill sites, and groundwater and surface water contamination by waste. The 
reduction in GHG emission consequently helps in regard to the issue of global warming/climate change (Hubbe et al. 2010).

Composting is a fundamental feature of an integrated solid waste management strategy. For effective integrated solid waste management, the key approaches are reducing, reusing, recycling, and managing waste to ensure environmental and human health safety. Local situations and needs vary from region to region and so does the composting process. Composting is a part of organic recycling, which converts organic waste into a nutrient-rich soil conditioner and also results in a reduction of GHG emissions (Lou and Nair 2009). The composting of different waste substrates is discussed in brief in the following subsections.

\subsection{Agricultural/Lignocellulosic Waste}

To maintain sufficient and long-lasting humus, biodegradable wastes, such as sawdust, wood shavings, coir pith, pine needles, and dry fallen leaves, are mixed together (Gajalakshmi and Abbasi 2008). However, it is observed that lignin-rich plant materials do not disintegrate rapidly. To enhance the decomposition, the waste material is treated with lime. They are mixed in a ratio of $5 \mathrm{~kg}$ of lime per $1000 \mathrm{~kg}$ of waste to prepare a good compost from hard plants. Lime can be in the form of dry powder or semi-solid substance when mixed with water. Liming weakens the lignin structure and enhances the humification process in plant residues, thus improving the humus quality (Hubbe et al. 2010). As an alternative to lime, phosphate rock in a dry powder state can be mixed in a ratio of $20 \mathrm{~kg}$ per $1000 \mathrm{~kg}$ of organic waste; it contains phosphates and micronutrients, which make a compost that is rich in plant nutrients.

\subsection{Sewage Sludge}

Sludge from sewage can be mixed with carbon by-products from agricultural sources, such as straw, sawdust, or wood chips, to produce compost. Microorganisms and parasites, which can cause diseases, are killed by the heat generated from bacteria digesting both sewage sludge and plant material in the presence of oxygen. Proper air circulation is obtained by maintaining aerobic conditions under 10-15\% oxygen and bulking agents like shredded tyres. Stiff materials separated from softer leaves and lawn clippings maintain better ventilation (Fang et al. 1999).

An insulating blanket of previously composted sludge is placed over aerated composting piles for uniform distribution of pathogen-killing temperatures. The composting mixture should have an initial moisture level of about 50\%, but if the temperature is inadequate for pathogen reduction, then the compost moisture content rises above $60 \%$. Hence, composting mixtures piled on concrete pads with built-in air ducts might improve air circulation (Fang et al. 1999). A blower drawing 
vacuum may be used to minimise odours. When the moisture reaches $70 \%$, exhausting through filtering pile can be replaced. The accumulated liquid in the underdrain ducting may be returned to the sewage treatment plant. For better moisture control, roofing of composting pads is required.

After a small interval that is sufficient for pathogen reduction, undigested bulking agents are recovered for reuse. The optimum initial carbon-to-nitrogen ratio of a composting mixture is between $26: 1$ and $30: 1$, but the amount required to dilute concentrations of toxic chemicals in the sludge to acceptable levels for the intended compost use determines the composting ratio of agricultural by-products. Agricultural by-products have less toxicity; however, suburban grass clippings containing residual herbicide levels are detrimental to some agrarian purposes, and freshly composted wood by-products may contain phytotoxins that inhibit the germination of seedlings until detoxified by soil fungi (Jouraiphy et al. 2005).

\section{$2.3 \mathrm{MSW}$}

Composting yard trimmings, agricultural wastes, and sewage sludge have increased the interest in composting of organic fractions from MSW. MSW contains materials that vary in size, moisture, and nutrient content, and the organic fractions can be mixed with varying degrees of non-compostable wastes and possibly hazardous constituents. Producing a market-savvy compost product requires a range of physical processing technologies, in addition to the biological process management (Varma and Kalamdhad 2013).

Modern MSW composting system consists of four tasks: collection, contaminant separation, sizing and mixing, and biological decomposition. The collection task is representative of the characteristics of the incoming waste, which largely determines the processing requirements of the remaining tasks. The separation task generates recyclable and rejects streams. Biological activity can be enhanced by increasing the surface area of the waste in size reduction, whereas mixing ensures the adequacy of nutrients, moisture, and oxygen in the material.

Evaluation of system design: Several criteria are important, like cost (capital, operations, and maintenance), market specifications for compost and recyclable byproducts, and system flexibility to respond to a changing MSW feedstock. The economic analysis of a composting facility should evaluate options like landfilling or incineration, along with different ways of achieving the same goal. It should also include analysis of cost between source separation, centralised separation, contaminant removal, and market assessment for recyclable by-product streams and the compost product (Wei et al. 2017). A composting facility should consider the quality control and product, as it might be a problem if a particular technology produces a less recyclable product as compared to markets. A flexible facility will be able to adapt to changes in the regulatory environment, in market specifications, and in the waste stream. Hence, the MSW facility should be flexible, in order to operate in the long term. 


\subsection{Biomedical Waste}

Biomedical waste needs to be pre-treated with $5 \%$ sodium hypochlorite $(\mathrm{NaOCl})$ at the disposal site for safety measures (Dinesh et al. 2010). It should be subjected to an initial decomposition process by blending it with cow dung slurry and can be further treated using the vermicomposting technique. Various epigeal species of worms can be utilised for this purpose. Practising this methodology for treating biomedical wastes can make these worms more efficient in carrying out the decomposition process. Vermicomposting with proper handling of biomedical waste can be an energy-efficient, eco-friendly approach for reducing and recycling this hazardous waste (Dinesh et al. 2010).

\section{Composting Techniques Used in India}

The organic fraction comprises the significant portion of waste generated in developing countries like India, and due to improper waste management practices, only a minor portion of the total waste volume is processed. The composting technique has been divided into two categories: the first category comprises conventional composting techniques, while the other category includes novel composting techniques. Each of the composting techniques is explained in brief in the following section. Figure 3.1 shows different composting techniques adopted for processing various types of biodegradable waste.

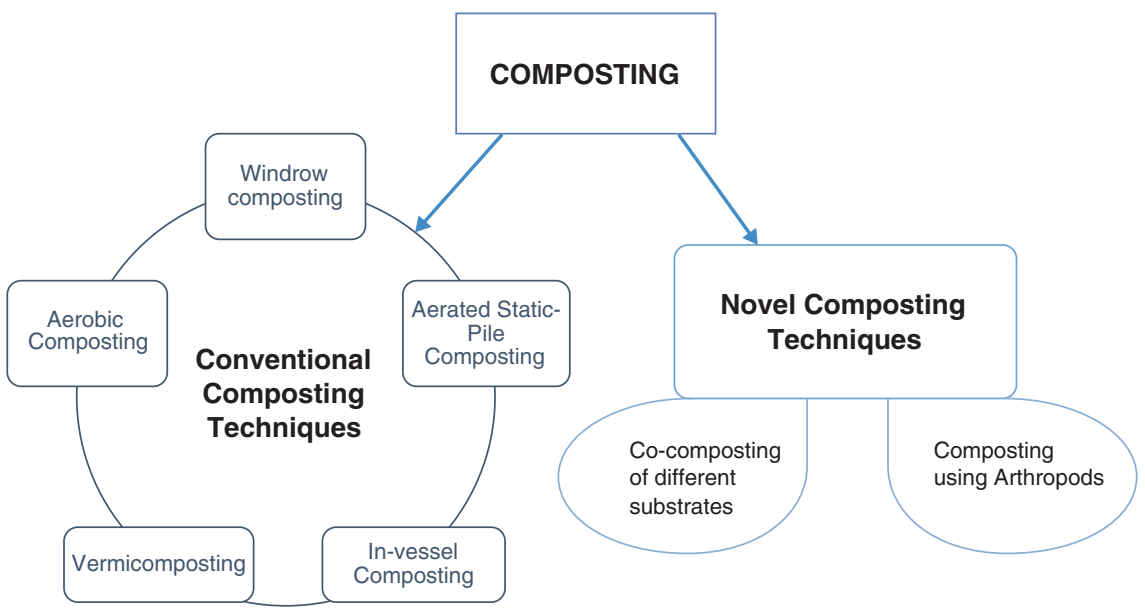

Fig. 3.1 Different composting techniques practised in India 


\subsection{Conventional Composting Techniques}

Windrow Composting In a windrow composting system, piles of waste are kept for the decomposition and aeration activity and are turned simultaneously. The turning of waste piles leads to the lowering of the temperature of the compost and also allows the circulation of air in the system. Windrow systems are comparatively economical since there is no such requirement of any mechanical tools for providing aeration. The height of the windrow depends on the type of waste substrate and the equipment or tool used for flipping purposes. The intermittent flipping of the waste heaps is necessary for maintaining the optimal temperature (Kumar 2011).

Aerated Static Pile Composting In an aerated static pile composting system, the waste substrate is decomposed without any physical activity over 30-35 days. Perforated pipes are used for providing aeration to the waste piles. These waste piles can be kept open, covered, semi-covered, or in windrow form. The rate of aeration is one of the most critical factors in this type of composting system. The asperity of aeration produces the vertical temperature difference within the entire structure of the waste pile (Hubbe et al. 2010).

Vermicomposting The process of vermicomposting involves the utilisation of earthworms of different species for the disintegration of semi-decomposed biodegradable waste. It has been found that the earthworms can consume up to five times their body mass every day. According to CPCB (CPCB 2013b) report, the total number of composting and vermicomposting plants located in several states of India are shown in Fig. 3.2. Earthworm species commonly used in the vermicomposting systems are Perionyx excavatus, Eudrilus eugeniae, and Eisenia foetida. These epigeal species are extremely prolific feeders which can devour diverse streams of organic waste.

Aerobic Composting The aerobic composting system is carried out in the presence of air at a specific temperature and $\mathrm{pH}$ range where the microbial consortia decompose the biodegradable waste into a nutrient-rich bio-fertiliser (Monson and Murugappan 2010). During the aerobic composting process, the optimal rate of aeration can solve the problem of odours.

In-vessel Composting The in-vessel composting system involves the decomposition of the organic fraction of the waste in a closed container or vessel in a controlled environment (Manyapu et al. 2017). Various in-vessel composting systems comprise rotating drums and agitated bags. Instinctive aeration and mechanical agitation can enhance the decomposition process and boost the rapid composting process. Motorised agitation may lead to contravention of particles, providing a healthier contact of the microorganisms with the carbon, while the higher temperature in the vessels can finish the pathogenic activities in the system, and an unceasing 


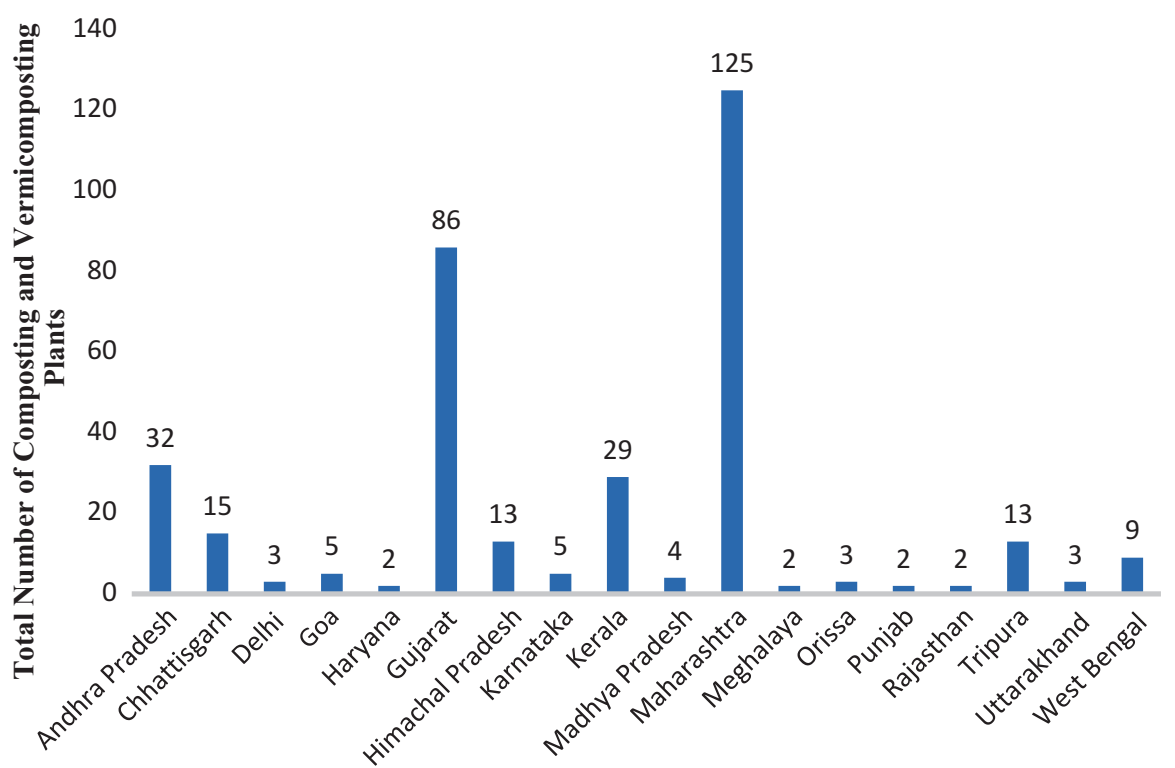

Fig. 3.2 Total number of composting and vermicomposting plants across India. (Source: CPCB 2013b)

aeration results in the removal of odours from the system (Monson and Murugappan 2010).

\subsection{Novel Composting Techniques}

To overcome the problems associated with conventional composting practices and to improve the efficiency of the composting system, different researchers and environmentalists throughout the globe have adopted various approaches for effectual composting of biodegradable waste; these are termed novel composting techniques in this chapter. One of the approaches, called the co-composting technique, involves the utilisation of different waste substrates; another approach involves utilisation of arthropods like millipedes, black soldier flies, and similar organisms for composting purposes. Both of these techniques are explained in brief in this section.

Co-composting of Different Waste Substrates This is a technique in which two different waste substrates are mixed together and applied to augment the composting activity. Co-composting of the waste substrate using specific type of bulking agent can offer sufficient particle structure and the denseness of the particles may tend to provide airspace needed for improving the aerobic microbial activity, leading to an increased rate of biodegradation. Various researchers have utilised food waste as a substrate for co-composting with other waste substrates because of their 
unique characteristics. Practising the co-composting of food waste can prove to be the best solution for processing food waste. Food waste can be blended with other waste substrates like chopped hay, rice husks, wooden chips, wheat straw, rice bran, sawdust, and other similar biodegradable waste to maintain the favourable carbon/ nitrogen $(\mathrm{C} / \mathrm{N})$ ratio, void spaces, moisture, and nitrogen content. The problem regarding the lower $\mathrm{pH}$ of the food waste can be solved by adding sodium acetate in the mixture of the waste, to balance the $\mathrm{pH}$ level of the system. Similarly, different feedstocks, like pig manure, poultry litter, etc., can be applied for co-composting activities with other supplementary waste substrates (Kumar et al. 2018).

Composting Using Arthropods Among the different techniques practised for the management of biodegradable waste, fertilising the soil is the most favoured one. In recent years, novel techniques have been developed for efficient composting of biodegradable waste, and various arthropods have been used in the composting process. Many species of insects are efficiently utilised for reprocessing and transforming waste of vegetal origin. The blends of different types of waste formed at diverse stages of decomposition entice an essential species of arthropods whose life cycle is over in the compost, while any further addition to it enhances the decomposition process. These arthropodal species boost the development of the consentient species (Kumar et al. 2018). Arthropods like millipedes and black soldier fly larvae have been successfully used by Karthigeyan and Alagesan (2011) and Diener et al. (2015) for the composting of different types of organic waste. The millipedes transform the waste substrate into faecal pellets, which affect the required physicochemical characteristics by decreasing the $\mathrm{C} / \mathrm{N}$ ratios (Karthigeyan and Alagesan 2011).

\section{Composting as a Technique for Solid Waste Management in the Indian Scenario}

Like other developing countries, India is also confronting solid waste management as one of the major issues it faces. Due to the expeditious growth in population, urbanisation, and industrialisation, India is switching towards an industrial and service-based economy and away from an agricultural-based economy. India has 29 states and 7 union territories and has climatic, geographical, ecological, cultural, traditional, and religious heterogeneity. The present urban population of India accounts for $31.2 \%$ (377 million) of its total population (Census 2011). As per CPCB (CPCB 2013b), India generated about 127,486 tonnes per day (TPD) of waste in 2011, out of which 89,334 TPD (70\%) was collected; only 15,881 (12.45\%) of the total waste was processed (CPCB 2013b). Being a developing country, the organic fraction of MSW in India is usually high. The urban MSW composition in Indian cities contains approximately $40 \%$ organic, $40 \%$ inert, and $19 \%$ of recyclable fractions (Sharholy et al. 2008). India has 279 composting plants, 138 
vermicomposting facilities, 172 bio-methanation processors, 29 pelletisation plants, and 34 landfill sites across the country (Planning Commission 2014). From the numbers, it can be understood that composting technology is the most favoured and recommended among all the other technologies for efficient waste management. The problem of waste management is still prevalent in the country and is one of the major concerns for urban local bodies, which govern the urban parts of the country. In spite of the facilities above, it is believed that $90 \%$ of waste in India is dumped in an unscientific manner (Gajalakshmi and Abbasi 2008). The average per capita waste generated ranges from approximately 0.17 to $0.62 \mathrm{~kg}$ depending on location, economic activity, and culture (Kumar et al. 2009). The rapid composting technique is highly encouraged in big Indian cities. Indore composting centre is one of the foremost maintained composting plants in the country. Considering different zones in India, the following subsections discuss the current scenario of composting in several cities, along with the overall scenario of composting on the ground level.

\subsection{Composting in the City of Kolkata}

Kolkata city is the capital of the state of West Bengal. According to the South Asian Forum for the Environment, Kolkata generates 4000 tonnes of waste per day, out of which 37\% is compostable (Dutta 2018). The major issue being faced by the Kolkata Municipal Corporation is the unavailability of land. The only landfill site in the region is "Dhapa", and it is already oversaturated from use over the last 30 years. The Dhapa dumpsite is located in the East Kolkata Wetlands, which is a Ramsar Convention Wetland. Dhapa dumpsite alone contributes to 7500 cubic metres of GHGs per hour (Times News Network 2013). According to a news daily, Kolkata city needs at least two solid waste treatment plants for the efficient management of waste (Dutta 2018). Keeping in view the massive problem of waste management, many housing complexes and societies have started installing compost machines within their premises for the treatment of MSW generated from household activities. The Belani Group of Companies, which is a housing development firm, has installed two composting facilities near the Hiland Riverside project in Batanagar. It has been announced that the Kolkata Municipal Corporation will be installing a similar composting facility in Tollygunge, Madhyamgram, and Rajarhat. These areas are among the most densely populated regions in Kolkata city and are also being developed at a rapid pace. Over 1100 apartments in South City (Residential Complex) in Kolkata have also joined this movement and have decided to sensitise the MSW for soon implementing the same mechanism in their housing complexes (Desai 2018). A small town in West Bengal named Uttarpara has helped Kolkata in receiving a prestigious award under the Urban Solid Waste Management category in the C40 Mayors' Summit held in Mexico on 1 December 2016, for its exclusive and effective solid waste management, which was mainly focussed on the segregation of waste at source. It was found that all the waste in Uttarpara is separated at source into biodegradable and non-biodegradable categories (Rao 2016). It has been 
reported that, earlier, a dumpsite, with debris ranging up to $50 \mathrm{ft}$. in length, was present in the town. However, a composting facility has been installed there and is operating successfully (Bhattacharya 2016). Nowadays, the composting facility at Uttarpara receives about 12-14 tonnes of raw biodegradable waste and produces 3 to 4 tonnes of manure per day (Rao 2016). The attitude of negligence towards the dumping site in Kolkata resulted in deplorable hygiene conditions and health impacts. Kolkata is a metropolitan city which is gradually moving towards a clean society. Small steps may gradually change the current scenario, but at the same time, the pace needs to be boosted to overcome the surging waste management problems.

Similarly, to promote sustainable waste management and utilise the nutrient-rich manure from composting processes, two female entrepreneurs from Kolkata, namely, Avantika Jalan and Rashmi Sarkar, have created a social enterprise called Mana Organics to recover soil fertility by producing chemical-free organic compost. Currently, they are operating four small composting projects: one in Tinsukia city, situated in the state of Assam, and the other three in villages in Madhya Pradesh. The compost produced from these composting facilities is marketed and sold in New Delhi and Kolkata. The firm started with a capital of 33.75 Lacs Rupees in 2011 (Basu 2014). Both entrepreneurs were inspired by their visit to Khargone district in the state of Madhya Pradesh. During their visit, they observed that a few regions in that district were devastated due to the failure of the cotton crop, and so they decided to help in solving the problem of the farmers (Basu 2014). The composting technique was adopted to manage the organic waste generated by agricultural and household activities to produce chemical-free organic manure, and they also spread awareness about the same among the farmers. Today, Mana Organics works with Adivasi (tribal) farmers in three villages of Madhya Pradesh: Sultanpur, Lachera, and Koriyakal (Basu 2014).

\subsection{The Scenario of Composting in Delhi}

Delhi is a union territory and the capital of India, and its present population is 11 million (Census 2011). According to a renowned environmental magazine, Down to Earth, Delhi generates 9500 TPD of waste, out of which 8000 TPD is collected and transported to three landfill sites, namely, Bhalswa, Ghazipur, and Okhla (Mudgal 2015). In some localities of the city, like Dwarka, Defence Colony, Sarita Vihar, Preet Vihar, and Dilshad Garden, composting facilities are already installed in their respective community parks, and segregation at source at the domestic level is being practised. The chairman of Delhi Municipal Corporation, Mr. Naresh Kumar, claimed that five localities in the state would become self-sustainable and would be transformed into a zero waste discharge site by the end of 2018 (Mudgal 2015). These five North Delhi Municipal localities are Pandara Park, Jor Bagh, Kaka Nagar, Bapa Nagar, and Golf Links. This idea was proposed in collaboration with a local resident welfare association. This plan emphasised segregation at source and 
separation into the wet waste, dry waste, and e-waste categories (Halder 2017). Delhi has three centralised composting plants at Narela, Bhalswa, and Okhla, which process around 500 TPD of biodegradable waste. Temples in Delhi are also coming forward to contribute to green practices. In Jhandewalan Temple, 5000-10,000 devotees visit every day, which results in the generation of $200 \mathrm{kgs}$ of floral waste per day. On Tuesdays and Sundays, the waste generation rises to $500 \mathrm{~kg}$, and during Navratri Puja (Goddess Festival), it goes up to about 1 TPD (Desai 2018).

In 2013 Delhi University invested 4 Lacs Rupees in the renowned college "Miranda House" to encourage composting within its premises to manage biodegradable waste most efficiently. The institute uses the raw material, comprising a mixture of horticulture and kitchen waste in a 1:3 ratio, for composting. The period required for composting is about 12-15 days (Mudgal 2015). The institute collaborated with Green Bandhu Environmental Solutions \& Services, and now they produce $60 \mathrm{kgs}$ of organic compost every day. It is encouraging the use of compost for recreational purposes in the region. The institute also earns around 4000-5000 Rupees by selling the supplementary compost produced from the composting plant and ultimately saves 12,000 Rupees which would have been incurred in the transport of waste (Mudgal 2015).

The General Pool Residential Complex in New Moti Bagh region is spread across 110 acres, with 1100 families. In 2013, this residential complex installed a composting facility provided by Green Planet Waste Management Pvt. Ltd. An area of $300 \mathrm{~m}^{2}$ was needed for the composting facility, which receives around $700 \mathrm{~kg}$ of kitchen waste and $900 \mathrm{~kg}$ of horticultural waste per day (Mudgal 2015). The period required to get a matured compost is 15-20 days, thus producing organic compost. The company invested about 8 million Rupees in setting up this plant, and now the operators are struggling to recover the expense invested in installing the facility. A financial crisis or losses may result in its failure (Mudgal 2015).

The Defence Colony in the state of Delhi is practising composting for its kitchen waste using effective microorganisms (EM1) microbial solution-based pit composting. The composting period for this technology is relatively high, at 3-4 months. This setup requires a land area of just $30 \mathrm{~m}^{2}$, costing 70,000 Rupees only (Mudgal 2015). The cost for every household served by this plant is 45 Rupees only, which is quite affordable. This setup was established by the Residential Welfare Association (RWA), with the help of a non-profit organisation named Toxics Link. Two rag pickers are trained by the RWA to operate the compost facility, and their wages are paid for from the compost facility itself.

Recently, the North Delhi Municipal Corporation has declared that it will shortly set up four "bio-methanation" and "aerobic drum compost plants" under its jurisdictions. The bio-methanation plants are proposed to deal with green waste, having an intake capacity of 5 TPD, and the compost plants will have a capacity of 1 TPD load. These plants will deal with green waste generated from RWAs, parks, and vegetable markets. The total expenditure for 5 years for the procurement, operation, and maintenance of the plants would be a minimum of 17.95 Crores (Adak 2018). 


\subsection{Status of Composting in Nagpur City}

Nagpur is the third largest city in the state of Maharashtra and ranks 13th in terms of population in India. Nagpur is a central part of India, with a population of more than 2.4 million (Census 2011). The average waste collection in Nagpur is 1119 TPD, out of which only 200 TPD is processed by Hanjer Biotech Energies Pvt. Ltd. This company produces 35-40 tonnes of compost daily, which is sold to Rashtriya Chemicals and Fertilizers (Times News Network 2017). A waste characterisation of Nagpur city was performed by CSIR-NEERI in all ten zones of the city. The sampling sites were decided based on different sources of wastes, viz. residential (slum and non-slum areas) and institutional areas, community bins, commercial areas, and disposal site. The household waste composition indicated a $77 \%$ organic fraction, $11.60 \%$ plastic, $7.66 \%$ paper, and $3.74 \%$ textiles and cardboard. However, the average value of all ten zones had a waste composition comprising $60 \%$ organic fraction, $15.50 \%$ plastic, $11.20 \%$ paper, $2.10 \%$ inerts, and the remaining $11 \%$ including wood, metal, glass, and other parts (Dutta 2017). The total waste dumped during the year 2016-2017 was estimated at approximately around 14,000 TPD by the Nagpur Municipal Corporation (NMC). Initially, the garbage was processed for bio-mining and then segregation, harrowing, and finally spraying of bio-cultures to speed up the degradation. This process proved effective in reducing the height of the piled waste to some extent. However, there is a need to market the produced compost. A recent massive fire and the unpleasant odour of the waste indicate that enormous challenges remain (Times News Network 2017).

The NMC also launched one project in June 2017 to deal with garden waste. This was a pilot project: they planned to include five gardens in the city and a women's self-help group in the processing of biodegradable waste. This initiative was undertaken to reduce the burden of waste, in terms of transportation, as well as at the dumpsite. Provision was made to utilise the compost produced by any garden in the same garden (Dutta 2017).

\subsection{The Scenario of Composting in Alappuzha and Thiruvananthapuram}

Alappuzha and Thiruvananthapuram are cities located in the state of Kerala in the southern part of India. The populations of Alappuzha and Thiruvananthpuram 1,74,176 and 7,43,691, respectively (Census 2011). The Centre for Science and Environment, which is a not-for-profit public interest research and advocacy organisation based in New Delhi, assessed the performance of 20 cities for waste segregation at source, transportation, waste processing, and adoption of decentralised systems. In this assessment, these two cities won the four-leaf award and were ranked second in position, after Vengurla, which is a town in the Sindhudurg district of Maharashtra. Under the "Clean Home, Clean City" (Nirmal Bhavan, Nirmal 
Gram) initiative, the Alappuzha established a pipe composting system, an aerobic composting system, and biogas plants. The municipality set up fixed as well as portable biogas plants in both residential and public places. According to the renowned magazine Down to Earth, this pilot project soon was successful and benefited almost 40,000 households in 52 wards (Agarwal 2017). This progress of waste management was the result of a protest in 2012 in response to the shutting down of the dumping site at Sarvodayapuram, where garbage had been dumped for decades. This protest turned into a movement, and cameras were installed to catch people who litter. Alappuzha saved approximately 11 Lacs Rupees on transportation and liquefied petroleum gas bills. The city was recognised by United Nations Environmental Programme (UNEP), alongside four other anti-pollution cities across the world. The other four cities in the list were Osaka (Japan), Ljubljana (Slovenia), Penang (Malaysia), and Cajica (Colombia) (Agarwal 2017).

In Thiruvananthapuram, composting is being practised at the household level. Thiruvananthapuram consists of 100 wards, and each ward has 2500-3000 households (Bhardwaj 2017). The residents receive assistance on the technical element of composting. For composting at the source, local service providers put forward a three-layered bin and 301 coco peat-based inoculum. The local service provider collects only the biodegradable waste. The technician will assist in the operations and also collects the compost if it is not required by the household and charges 200 Rupees monthly for providing the services (Bhardwaj 2017). The residents are also encouraged to use biodegradable products and to boycott non-biodegradable products through a programme called "Green Protocol", which was launched by the state government of Kerala during the Onam celebrations, which is Kerala's grand festival.

\subsection{The Overall Scenario of Composting in India}

Organic matter makes up more than 65\% of MSW generated in India (NEERI Report 2012). If this organic fraction of MSW is processed by employing technologies like composting and anaerobic digestion, it can result in a reduction of $50 \%$ of the load on landfill sites. In India, only $10-12 \%$ of the total MSW is processed by means of composting, and the resulting compost possesses a poor nutrient value and mostly contains heavy metals like zinc, copper, lead, cadmium, lead, nickel, and chromium in higher concentrations as compared to the prescribed standard for compost (Hoornweg et al. 2000 and Waste to Energy Research Council 2012). This poor quality of compost is mainly due to the mixed nature of the waste (Hoornweg et al. 2000). Due to a lack of a continuous supply of feedstock to the compost plant and improper management, composting of biodegradable waste is not successful at large scale in India.

Similarly, improper segregation of waste, higher costs involved in the operation and maintenance of composting plants, and higher costs of manure than chemical fertiliser are major reasons for its non-viability in the Indian context (UNEP 2004). 
From a field survey, it was observed that many places in India face a failure of composting plants. For example, a windrow composting plant at Durgapur (300 TPD) and Kamarhati (200 TPD), West Bengal, was not able to achieve sales breakeven point due to issues with the waste characteristics; the plants are about to close. In the same state of West Bengal, the vermicompost plant at Chandannagar and Kalyani is performing well, but the vermicompost plants at Panihati (100 TPD), Bhadreshwar (20 TPD), and Khardah (30 TPD) are in poor shape because of the large variation in the waste characteristics and lack of supervision in the quality control of the product. The same situation applies to the vermicomposting plant (50 TPD) at Bidhannagar. The Kolkata Municipal Corporation is operating a 200 tonnes capacity windrow composting plant sporadically, at less than one-fourth of its capacity, due to the variation in waste characteristics. The compost plants at Mangalore (300 TPD) and Mysore (400 TPD) in the state of Karnataka and a 500 TPD compost plant situated at Nasik in the state of Maharashtra are also processing at lower plant capacity (Aich and Ghosh 2019).

\section{Capacity Building Efforts: Strategies and Schemes Launched by the Government of India}

Indian MSW management has good potential for composting as waste because it contains a significant amount of organic waste. A decentralised composting system is an appropriate option for India to efficiently run a composting unit. The Indian Government is also encouraging decentralised composting systems, since many environmentalists, policymakers, and researchers have advised that composting is the most feasible and effective waste management technique, in comparison to other techniques (Aich and Ghosh 2019). The government has also developed schemes for MSW capacity building in the country (Ministry of Chemicals and Fertilisers (MOC\&F) 2017). Door-to-door waste collection and segregation at the source aid in the collection of waste that has similar characteristics and its disposal at the right place in an economical and efficient manner. A Market Development Assistance scheme has also been launched to enhance capacity building for the compost market. The Indian Government is encouraging all stages of capacity building for city compost. In the last few years, all countries throughout the globe have begun developing strategies for the management of solid waste in a sustainable manner. Composting, as a part of integrated solid waste management, is effective in almost all scenarios. In view of this, the Government of India has also framed different policies and strategies to encourage the practice of composting in India. Schemes like "Swachh Bharat Mission" promote the concept of cleaner and greener cities. Most of the challenges related to the efficient management of MSW in the country are stated in the CPHEEO (2016). The management of solid waste in the country is among the key factors in urban development, and for this reason, the Government of India has launched different schemes, including the Atal Mission for Rejuvenation 
and Urban Transformation (AMRUT), Jawaharlal Nehru National Urban Renewal Mission (JNNURM), Swachh Bharat Mission, and Smart Cities Mission. In these schemes, solid waste management is generally associated with the water supply system, storm drain system, and sewerage system. Regarding organic waste management, in particular, one recent report, "34th Report on Implementation of Policy on Promotion of City Compost", was presented in the Parliament (Lok Sabha) on 10 April 2017. This report addressed one of the most serious problems associated with urbanisation. According to this report, the stated framework of City Compost is explained in the following section:

- The "Swachh Bharat Mission" scheme is very closely associated with organic waste processing and its use as compost. Hence it can be considered as a rational part of this scheme.

- The composting process helps in reducing the amount of waste at landfill sites.

- Composting also prevents GHG emissions and harmful toxic materials from leaching into groundwater.

- The organic carbon constituent of compost is useful in maintaining and improving soil fertility.

- According to the Ministry of Urban Development, the entire potential of city compost plant in India is $0.71 \mathrm{MT}$ per year, while the current production is 0.15 MT per year.

In the view of this, the MOC\&F of the Government of India released a notification in Parliament (Lok Sabha), dated 10 February 2016, to promote city compost schemes (MOC\&F 2017). The key features of the scheme are as follows:

(i) An amount of 1500/- Rupees will be provided per tonnes of city compost in the form of marketing development, which in turn will encourage the manufacturing and marketing of the city compost.

(ii) At the initial stage, the existing fertiliser manufacturer will be promoted by the marketing of city compost. Meanwhile, other marketing entities marked by concerned state governments may also be involved, with the approval of the Department of Fertilisers.

(iii) The manufacturer involved in the promotion and sale of city compost may get a subsidy as per the decision of the Department of Fertilisers.

(iv) A fertiliser manufacturer can co-market city compost with chemical fertilisers through their network in the market.

(v) Companies will adopt the village to encourage city compost utilisation.

(vi) The government and public sectors in India will also promote the use of city compost for their gardens and horticulture, to the greatest possible extent.

(vii) Farmers should be educated about the benefits of city compost through information, education, and communication campaign conducted by the Department of Agriculture, Cooperation, and Farmers' Welfare. Agricultural universities will also participate in the same.

(viii) The Ministry of Urban Development will look after installations of the compost plants across the state. 
(ix) A Bureau of Indian Standards (BIS) or eco-mark will be developed with the association of BIS to ensure good quality of compost and so its acceptance among farmers.

(x) Government bodies like the Department of Agriculture and Fertilisers and the Ministry of Urban Development will be involved in monitoring to provide information on the availability of city compost. This mechanism will help compost manufacturers and fertiliser marketing concerning coordination issues.

(xi) Expenditure on market development assistance will be met from the budget provision for the Department of Fertilisers.

As a result of this notification, fertiliser companies have adopted 100 villages to promote the city compost. After the implementation of this policy, the production of compost plants is expected to increase, and the target is the processing of $100 \%$ of MSW. Significant results are expected to be seen in a year (MOC\&F 2017). Decentralised composting units are a feasible option, but skilled manpower is required in good strength. The Indian Government is helping right from waste pickers to farmers with appropriate schemes for the efficient management of organic waste in a sustainable manner.

The Indian Government is also taking steps towards spreading awareness among citizens and by providing e-learning for MSW practices. These courses involve case studies to explain the appropriate options for particular situations. Specialised courses on composting are included in the subcategory of the 200 series $(205,206$, 214, 217, 230, 235, and 252) (CPHEEO 2016). This course has been designed to systematically enhance capacity building on composting in India. These courses comprise several case studies of Indian cities, such as Vijayawada, Coimbatore, Bengaluru, Thiruvananthapuram, and Kochi. Apart from the case studies, these courses offer training on choosing suitable composting facilities (CPHEEO 2016).

\section{Conclusion and Recommendations}

Composting has been practised in India for a long time. However, the extent of its use is surging with time and need. At present, waste management has become a major challenge due to the unscientific practices of waste management observed in the past few decades. Composting technology can be successful or may fail: this depends on its planning and execution. Decentralised composting is burgeoning in India, as the management of smaller units is comparatively easier than bigger units, and the installation cost also affects the financial sustainability of the operational plant. Implementing composting plants of greater capacity generally requires huge investments, and recovering the invested amounts becomes difficult; thus, the losses incurred may lead to the closure of the plants. As discussed earlier, the installation of decentralised smaller composting units is effective at the ground level (MHUA 2018). 
One of the major factors in the sustenance of composting plants is community participation. The active participation of the general masses is extremely important; if waste is segregated at the source itself, then the management of waste can be done most effectively. Earlier, the Indian population was negligent towards waste segregation; however, changes in behaviour started when Indians started experiencing the unpleasant views, odours, and health issues that arise due to growing volumes of MSW left unmanaged. Moreover, awareness of the health risks related to unprofessional MSW management has increased. Cities like Alappuzha, Thiruvananthapuram, Mysuru, Panjim, and Panchgani are progressing towards the concept of zero waste discharge and becoming self-sustainable cities. In mega metro cities, adopting composting technology for effective waste management is still a major issue, due to behemoth volumes of waste generation, and in big cities, composting is still a big issue as the amount of waste generated is too huge to manage.

Busy lifestyles, coupled with higher living standards, in the urban parts of the country have also led to negligence regarding the management of waste. However, the critical steps taken by the government to manage generated wastes and put to better use have also resulted in a change in the perspective of the general population. It has been observed that the population is becoming aware of problems associated with effective waste management and is becoming more conscious regarding the effectual management of waste. People are sensitised about this topic, and they are trying to involve themselves more in waste management activities.

Adopting composting techniques for processing organic waste has shown a fair reduction in emissions, as well as in the cost involved in different waste management techniques. Cities with successful operation composting facilities are inspiring other cities to adopt the same, thus resulting in a reduction in their investment and emissions. Apart from these benefits, the general population is also experiencing health benefits, which are also extremely important. If the metro cities plan to install large-scale composting units, precise planning for the recovery of cost should be done in advance by forming various market strategies. It will always prove beneficial to install and operate a pilot-scale composting unit rather than directly going for large-scale composting plants. A reconnaissance study of the concerned region, along with the characteristics of the waste and the acceptance of the technology, should be carried out before the installation of the composting plants. Different urban parts of the country are gradually coming forward to join the initiative for sustainable waste management in India. The government is also encouraging them to manage their waste by providing technical assistance, subsidies for plant installation, and a compost market. The government schemes and strategies are also playing a paramount role in successful compost plant operation.

As described in previous sections, several schemes supporting the composting of organic waste generated from the urban regions of the country have been launched and promoted by the Government of India. Despite all the policies and schemes framed by the government, their implementation on the ground level is still a major challenge. From experience, it has been found that the ruling government has tried to implicate all the perspectives of a composting technique for making it feasible. Different states in the country have different perspectives on and different visions of 
composting. Sates which have been practising composting for a few years have a commercial approach, while states in the country which are planning to adopt composting to manage their waste have a sustainable approach, ultimately resulting in sustainable development. The efforts taken by the government to promote composting technology should be appreciated, and the policies should be strictly followed to ensure their successful implementation. It is the fundamental duty of every citizen to consider their country as their own home and to take care to keep it green and clean.

\section{References}

Adak, B. (2018). North Delhi to get green waste compost plant. India Today. Available at: https://www.indiatoday.in/mail-today/story/north-delhi-to-get-green-waste-compostplant-1283362-2018-07-12. Accessed 3 Oct 2018.

Agarwal, R. (2017). Alappuzha gets recognised by UNEP for its solid waste management practices. DowntoEarth. Available at: https://www.downtoearth.org.in/news/alappuzha-gets-recognized-by-unep-for-its-solid-waste-management-practices-59258. Accessed 3 Oct 2018.

Aich, A., \& Ghosh, S. K. (2019). Conceptual framework for municipal solid waste processing and disposal system in India. In Waste management and resource efficiency (pp. 91-107). Singapore: Springer.

Basu, T. (2014). New law of the land: Compost or perish, The Hindu Business Line. Available at: https://www.thehindubusinessline.com/news/variety/new-law-of-the-land-compost-or-perish/ article23030221.ece. Accessed 2 Oct 2018.

Belyaeva, O. N., \& Haynes, R. J. (2009). Chemical, microbial and physical properties of manufactured soils produced by co-composting municipal green waste with coal fly ash. Bioresource Technology, 100, 5203-5209.

Bhardwaj, D. (2017). With the help of residents, this is how Trivandrum is composting its own waste. The Better India.

Bhattacharya, S. (2016). A tiny town in West Bengal is turning waste into piles of wealth. Hindustan Times.

Census. (2011). Primary census abstracts. Registrar General of India, Ministry of Home Affairs, Government of India.

CPCB. (2013a). CPCB annual report 2011-12. Ministry of environment. Forest and Climate Change, Government of India.

CPCB. (2013b). Status report on municipal solid waste management 1-13. Ministry of Environment, Forest and Climate Change, Government of India.

CPHEEO. (2016). Swachh Bharat mission municipal solid waste management manual. Central Public Health \& Environmental Engineering Organisation. Ministry of Housing and Urban Affairs, Government of India.

Desai, K. (2018). How these temples give a new life to old flowers. The Times of India. Available at: https://timesofindia.indiatimes.com/india/how-these-temples-give-a-new-life-to-old-flowers/articleshow/65762167.cms. Accessed 3 Oct 2018.

Diener, S., Zurbrügg, C., \& Tockner, K. (2015). Bioaccumulation of heavy metals in the black soldier fly, Hermetia illucens and effects on its life cycle. Journal of Insects as Food and Feed, 1, 261-270.

Dinesh, M. S., Geetha, K. S., Venugopalan, V., Kale, R. D., \& Murthy, V. K. (2010). Ecofriendly treatment of biomedical wastes using epigeic earthworms. Journal of Indian Society of Hospital Waste Management, 9(1). 
Dutta, S., (2017). From composting garden waste to treating 200 tonnes of waste daily, Nagpur's techniques show its all round efforts in improving waste management. Swachh India. Accessed 3 Oct 2018.

Dutta, S. (2018). Kolkata municipal corporation's waste management practices come under state pollution control board's scanner. Swachh India. Accessed 2 Oct 2018.

Fang, M., Wong, J. W. C., Ma, K. K., \& Wong, M. H. (1999). Composting of sewage sludge and coal fly ash: Nutrient transformations. Bioresource Technology, 67, 19-24.

Gajalakshmi, S., \& Abbasi, S. A. (2008). Solid waste management by composting: State of the art. Critical Reviews in Environmental Science and Technology., 38(5), 311-400.

Halder, R. (2017). Five colonies of Central Delhi to turn zero-waste by 2018. Hindustan Times.

Hoornweg, D., \& Bhada-Tata, P. (2012). What a waste: A global review of solid waste management. ANNEX J: MSW generation by country - Current data and projections for 2025 (Urban Development Series). Washington, DC: The World Bank.

Hoornweg, D., Thomas, L., \& Otten, L. (2000). Composting and its applicability in developing countries (Working Paper Series 8). Washington DC: The World Bank.

Hubbe, M. A., Nazhad, M., \& Sánchez, C. (2010). Composting as a way to convert cellulosic biomass and organic waste into high-value soil amendments: A review. BioResources, 5, 2808-2854.

Jouraiphy, A., Amir, S., El Gharous, M., Revel, J. C., \& Hafidi, M. (2005). Chemical and spectroscopic analysis of organic matter transformation during composting of sewage sludge and green plant waste. International Biodeterioration and Biodegradation, 56, 101-108.

Karthigeyan, M., \& Alagesan, P. (2011). Millipede composting: A novel method for organic waste recycling. Recent Research in Science and Technology, 3(9), 62-67.

Kumar, S. (2011). Composting of municipal solid waste. Critical Reviews in Biotechnology, 31, $112-136$.

Kumar, S., Bhattacharyya, J. K., Vaidya, A. N., Chakrabarti, T., Devotta, S., \& Akolkar, A. B. (2009). Assessment of the status of municipal solid waste management in metro cities, state capitals, class I cities, and class II towns in India: An insight. Waste Management, 29, 883-895.

Kumar, S., Negi, S., Mandpe, A., Singh, R. V., \& Hussain, A. (2018). Rapid composting techniques in Indian context and utilization of black soldier fly for enhanced decomposition of biodegradable wastes: A comprehensive review. Journal of Environmental Management, 227, 189-199.

Lou, X. F., \& Nair, J. (2009). The impact of landfilling and composting on greenhouse gas emissions: A review. Bioresource Technology, 100, 3792-3798.

Manyapu, V., Mandpe, A., \& Kumar, S. (2017). Synergistic effect of fly ash in in-vessel composting of biomass and kitchen waste. Bioresource Technology, 251, 114-120.

Ministry of Housing and Urban Affairs (MHUA). (2018). Urban advisory on on-site and decentralized composting of municipal organic waste. Swachh Bharat Mission.

MOC\&F. (2017). Standing committee on chemicals and fertilizers (2014-15).

Monson, C. C., \& Murugappan, A. (2010). Developing optimal combination of bulking agents in an in-vessel composting of vegetable waste. E-Journal of Chemistry, 7, 93-100.

Mudgal, S., (2015). Make wealth from waste, DowntoEarth. Available at: https://www.downtoearth.org.in/coverage/waste/make-wealth-from-waste-47164. Accessed 3 Oct 2018.

National Environmental Engineering Research Institute (NEERI) Report. (2012). Optimisation of organic waste to energy systems in India.

Planning Commission. (2014). Report of the task force on waste to energy: Volume I. Task Force Waste to Energy, I, 1-178.

Ramachandra, T. V., Bharath, H. A., Kulkarni, G., \& Han, S. S. (2018). Municipal solid waste: Generation, composition and GHG emissions in Bangalore, India. Renewable and Sustainable Energy Reviews, 82, 1122-1136.

Rao, P.V. (2016). A small town in West Bengal helped Kolkata win a global award for waste management. The Better India.

Sharholy, M., Ahmad, K., Mahmood, G., \& Trivedi, R. C. (2008). Municipal solid waste management in Indian cities: A review. Waste Management, 28, 459-467. 
Times News Network. (2013). Only one-tenth of waste recycled in Kolkata: Study. The Times of India.

Times News Network. (2017). Nagpur Municipal Corporation to convert garden waste into compost. The Times of India.

Tomić, T., \& Schneider, D. R. (2017). Municipal solid waste system analysis through energy consumption and return approach. Journal of Environmental Management, 203, 973-987.

UNEP. (2004). State of waste management in South East Asia..

Vandergheynst, J. (2009). Compost processing and its relationship to compost quality. Biological and Agricultural Engineering, UC Davis.

Varma, S. V., \& Kalamdhad, A. S. (2013). Composting of Municipal Solid Waste (MSW) mixed with cattle manure. International Journal of Environmental Sciences, 3(6), 2068-2079.

Waste to Energy Research Council. (2012). Sustainable solid waste management in India. Earth Engineering Centre Columbia.

Wei, Y., Li, J., Shi, D., Liu, G., Zhao, Y., \& Shimaoka, T. (2017). Environmental challenges impeding the composting of biodegradable municipal solid waste: A critical review. Resources, Conservation and Recycling, 122, 51-65.

The opinions expressed in this chapter are those of the author(s) and do not necessarily reflect the views of the United Nations University Institute for Integrated Management of Material Fluxes and of Resources (UNU-FLORES), its Board of Directors, or the countries they represent.

Open Access This chapter is licensed under the terms of the Creative Commons Attribution 3.0 IGO license (https://creativecommons.org/licenses/by/3.0/igo/), which permits use, sharing, adaptation, distribution and reproduction in any medium or format, as long as you give appropriate credit to the United Nations University Institute for Integrated Management of Material Fluxes and of Resources (UNU-FLORES), provide a link to the Creative Commons license and indicate if changes were made.

Any dispute related to the use of the works of the United Nations University Institute for Integrated Management of Material Fluxes and of Resources (UNU-FLORES) that cannot be settled amicably shall be submitted to arbitration pursuant to the UNCITRAL rules. The use of the United Nations University Institute for Integrated Management of Material Fluxes and of Resources (UNU-FLORES)'s name for any purpose other than for attribution, and the use of the United Nations University Institute for Integrated Management of Material Fluxes and of Resources (UNU-FLORES)'s logo, shall be subject to a separate written license agreement between the United Nations University Institute for Integrated Management of Material Fluxes and of Resources (UNU-FLORES) and the user and is not authorized as part of this CC-IGO license. Note that the link provided above includes additional terms and conditions of the license.

The images or other third party material in this chapter are included in the chapter's Creative Commons license, unless indicated otherwise in a credit line to the material. If material is not included in the chapter's Creative Commons license and your intended use is not permitted by statutory regulation or exceeds the permitted use, you will need to obtain permission directly from the copyright holder.

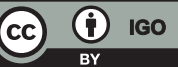

